OPEN ACCESS

Edited by:

Ashok Kumar,

University of Florida, United States

Reviewed by:

David Pubill,

Universitat de Barcelona, Spain

Alcino J. Silva

University of California, Los Angeles,

United States

*Correspondence:

Ling Chen

lingchen@njmu.edu.cn

Liandong Zhao

zldong@163.com

${ }^{\dagger}$ These authors have contributed equally to this work.

Specialty section:

This article was submitted to

Neuropharmacology,

a section of the journal

Frontiers in Pharmacology

Received: 23 November 2017

Accepted: 28 March 2018

Published: 12 April 2018

Citation:

Chen T, Wang Y, Zhang T, Zhang B,

Chen L, Zhao L and Chen L (2018)

Simvastatin Enhances Activity and Trafficking of $\alpha 7$ Nicotinic

Acetylcholine Receptor

in Hippocampal Neurons Through PKC and CaMKII Signaling Pathways.

Front. Pharmacol. 9:362.

doi: 10.3389/fphar.2018.00362

\section{Simvastatin Enhances Activity and Trafficking of $\alpha 7$ Nicotinic Acetylcholine Receptor in Hippocampal Neurons Through PKC and CaMKII Signaling Pathways}

\author{
Tingting Chen ${ }^{1,2+}$, Ya Wang ${ }^{2 t}$, Tingting Zhang ${ }^{1,2}$, Baofeng Zhang'2, Lei Chen², \\ Liandong $\mathrm{Zhao}^{3 *}$ and Ling Chen ${ }^{1,2 *}$
}

${ }^{1}$ State Key Laboratory of Reproductive Medicine, Nanjing Medical University, Nanjing, China, ${ }^{2}$ Department of Physiology, Nanjing Medical University, Nanjing, China, ${ }^{3}$ Department of Neurology, Huaian Second People's Hospital, Huaian, China

Simvastatin (SV) enhances glutamate release and synaptic plasticity in hippocampal CA1 region upon activation of $\alpha 7$ nicotinic acetylcholine receptor ( $\alpha 7 \mathrm{nAChR})$. In this study, we examined the effects of SV on the functional activity of $\alpha 7 n A C h R$ on CA1 pyramidal cells using patch-clamp recording and explored the underlying mechanisms. We found that the treatment of hippocampal slices with SV for $2 \mathrm{~h}$ induced a dosedependent increase in the amplitude of ACh-evoked inward currents $\left(I_{\mathrm{ACh}}\right)$ and the level of $\alpha 7 n A C h R$ protein on the cell membrane without change in the level of $\alpha 7 n A C h R$ phosphorylation. These SV-induced phenotypes were suppressed by addition of farnesol $(\mathrm{FOH})$ that converts farnesyl pyrophosphate, but not geranylgeraniol. Similarly, the farnesyl transferase inhibitor FTI277 was able to increase the amplitude of $I_{\text {ACh }}$ and enhance the trafficking of $\alpha 7 n A C h R$. The treatment with SV enhanced phosphorylation of CaMKII and PKC. The SV-enhanced phosphorylation of CaMKII rather than PKC was blocked by $\mathrm{FOH}$, Src inhibitor PP2 or NMDA receptor antagonist MK801 and mimicked by FTI. The SV-enhanced phosphorylation of PKC was sensitive to the IP3R antagonist 2-APB. The SV-increased amplitude of $I_{\text {ACh }}$ was suppressed by PKC inhibitor GF109203X and Go6983, or CaMKII inhibitor KN93. The SV- and FTI-enhanced trafficking of $\alpha 7 n A C h R$ was sensitive to KN93, but not GF109203X or Go6983. The PKC activator PMA increased $\alpha 7 n A C h R$ activity, but had no effect on trafficking of $\alpha 7 n A C h R$. Collectively, these results indicate that acute treatment with SV enhances the activity and trafficking of $\alpha 7 \mathrm{nAChR}$ by increasing PKC phosphorylation and reducing farnesyl-pyrophosphate to trigger NMDA receptor-mediated CaMKII activation.

\footnotetext{
Keywords: simvastatin, $\alpha 7$ nicotinic acetylcholine receptor $(\alpha 7 n A C h R)$, farnesyl pyrophosphate (FPP), farnesyl transferase inhibitor (FTI), protein kinas C (PKC), calmodulin-kinase II (CaMKII)
}

\section{INTRODUCTION}

Statins, which are inhibitors of 3-hydroxy-3-methyl-glytarylcoenzyme A (HMA-CoA) reductase, have received much attention due to the lower prevalence of Alzheimer's disease (AD) and/or dementia in patients treated with these drugs (Wolozin et al., 2000). In a 26-week randomized placebo-controlled double-blind trial, treatment with simvastatin (SV) improved cognitive 
functions in normal cholesterolemic AD patients (Simons et al., 2002). Treatment with SV can improve cognition in AD patients through a mechanism unrelated to its cholesterol-lowering effects (Jick et al., 2000).

Pathological studies on the brains of humans with $\mathrm{AD}$ revealed $\alpha 7$ nicotinic acetylcholine receptor ( $\alpha 7 \mathrm{nAChR})$ localizes in neuritic plaques (Wang et al., 2000). The decline of $\alpha 7 \mathrm{nAChR}$ level and dysfunction of $\alpha 7 \mathrm{nAChR}$ have been found in the brains of AD patients (Burghaus et al., 2000; Kihara et al., 2004). One important characteristic of $\alpha 7 \mathrm{nAChR}$ is its high permeability to $\mathrm{Ca}^{2+}$, thus $\alpha 7 \mathrm{nAChR}$ plays an important role in synaptic plasticity and cognitive function (Sharma and Vijayaraghavan, 2003; Chen et al., 2016a). The dysfunction of $\alpha 7 n A C h R$ is known to be critical pathogenic process and mechanism of cognitive disorder in AD (Chen et al., 2006). The coapplication of mevastatin and myriocin has been reported to alter the desensitization kinetics of $\alpha 7 \mathrm{nAChR}$ in the membrane (ColonSaez and Yakel, 2011). The chronic administration of SV in mice enhances the presynaptic glutamate release and facilitates the hippocampal long-term potentiation induction via the activation of $\alpha 7 \mathrm{nAChR}$ (Chen et al., 2016a).

Statins not only reduce de novo cholesterol biosynthesis, but also prevent the conversion of 3-hydroxy-3-methylglytarylcoenzyme A into mevalonate, leading to reduction of non-sterol intermediates known as isoprenoids (Endo, 2004). Two types of isoprenoids, farnesyl-pyrophosphate (FPP) and geranylgeranyl-pyrophosphate (GGPP), are essential for the prenylation of small GTP-binding proteins (GTPases) (McTaggart, 2006). The treatment with SV results in a reduction in FPP level followed by a decline in GGPP and cholesterol levels (Eckert et al., 2009). The chronic or acute administration of SV can enhance the induction of long-term potentiation through the reduction of FPP and inhibition of farnesylation (Mans et al., 2012; Chen et al., 2016a). The farnesylated proteins include the Ras superfamily of GTPases (e.g., H-Ras, K-Ras, and N-Ras) (Kho et al., 2004; McTaggart, 2006). The activation of Ras modifies downstream effectors protein kinase C (PKC) (Dann et al., 2014) and Src (Thornton et al., 2003). Phosphorylation of PKC can modulate the $\mathrm{Ca}^{2+}$ channels of $\alpha 7 \mathrm{nAChR}$ (Huganir and Greengard, 1990). We have recently reported that the administration of SV can increase Src phosphorylation leading to augmentation of NMDAr activity (Chen et al., 2016b). $\mathrm{Ca}^{2+/}$ calmodulin-dependent protein kinase II (CaMKII) is activated in hippocampal neurons by the increasing $\mathrm{Ca}^{2+}$ influx through NMDAr channels. The activating CaMKII is able to enhance the response of $\alpha 7 \mathrm{nAChR}$ (Kanno et al., 2012a). In addition, Serine 365 in the M3-M4 cytoplasmic loop of the $\alpha 7 \mathrm{nAChR}$ is a phosphorylation site for protein kinase A (PKA) (Moss et al., 1996). The disruption of lipid rafts affects the localization and mobility of $\alpha 7 \mathrm{nAChR}$ (Oshikawa et al., 2003). Collectively, we hypothesized that the acute treatment with SV is able to regulate the activity and trafficking of $\alpha 7 \mathrm{nAChR}$.

In the present study, we focused on the acute roles of SV and farnesyl transferase inhibitor (FTI) in the activity, trafficking and phosphorylation of $\alpha 7 \mathrm{nAChRs}$ in hippocampal CA1 pyramidal cells. We further examined the effects of SV and FTI on
PKC-, PKA-, and CaMKII-signaling pathways and explored the underlying mechanisms of SV-altered $\alpha 7 \mathrm{nAChR}$ activity and trafficking. Our results in this study indicate that acute treatment with SV enhances the activity and trafficking of $\alpha 7 \mathrm{nAChR}$ by increasing phosphorylation of PKC and reducing FPP to promote the CaMKII signaling pathway.

\section{MATERIALS AND METHODS}

\section{Experimental Animals}

The present study was approved by Animal Care and Ethical Committee of Nanjing Medical University. All animal handling procedures followed the guidelines of Institute for Laboratory Animal Research of the Nanjing Medical University. The procedures involving animals and their care were conducted in conformity with the ARRIVE guidelines of Laboratory Animal Care (Kilkenny et al., 2012). Postnatal 28-32 days male mice (ICR, Oriental Bio Service Inc., Nanjing) were used. The animals were maintained in a constant environmental condition (temperature $23 \pm 2{ }^{\circ} \mathrm{C}$, humidity $55 \pm 5 \%$, 12:12 $\mathrm{h}$ light/dark cycle) in the Animal Research Center of Nanjing Medical University. They had free access to food and water.

\section{Preparation and Administration of Drugs}

Simvastatin (Enzo Life Sciences International, Farmingdale, NY, United States) was converted from its inactive lactone prodrug form to its active dihydroxy open acid form by alkaline hydrolysis (Mans et al., 2010). SV (50 mg) was dissolved in $1 \mathrm{ml}$ ethanol (100\%), and then added by $0.813 \mathrm{ml} \mathrm{NaOH}(\mathrm{l} \mathrm{N})$, and the resulting solution was stored in aliquots at $-20^{\circ} \mathrm{C}$ (for up to 1 month). The stock solution was neutralized with $1 \mathrm{~N} \mathrm{HC1}$ to $\mathrm{pH}$ of 7.4 and diluted in artificial cerebral spinal fluid (ACSF).

Trans, trans-farnesol (FOH, 96\%, Cat\# 277541) and Geranylgeraniol (GGOH, 85\%, Cat\# G3278) were purchased from Sigma (St. Louis, MO, United States). FOH and GGOH were initially pipetted into ethanol, and then diluted by ACSF to final concentration of $0.01 \%$ ethanol.

Farnesyl transferase inhibitor (FTI, FTI-277) was purchased from Calbiochem (Cat\# 344555) (Darmstadt, Germany). FTI $(250 \mu \mathrm{g})$ was dissolved in $559 \mu \mathrm{l}$ dimethyl sulfoxide (DMSO) to prepare the stock solution at $1 \mathrm{mM}$ concentration.

The $\alpha 7 n A C h R$ agonist acetylcholine (ACh), $\alpha 7 n$ AChR antagonist methyl-lycaconitine (MLA), NMDA inhibitor MK801, Src inhibitor PP2, PKC inhibitor GF109203X (GF) and Go6983 (Go), PKC agonist phorbol 12-myristate 13-acetate (PMA) and inositol-1,4,5-trisphosphate receptor (IP3R) antagonist 2-APB were purchased from Sigma (St. Louis, MO, United States), PKA inhibitor H89 and CaMKII inhibitor KN93 were purchased from Medchem express (NJ, United States). The drugs were dissolved in DMSO and diluted by ACSF to a final $0.1 \%$ concentration of DMSO.

\section{Hippocampal Slices Preparation}

The mice were deeply anesthetized with isoflurane and decapitated. The brains were rapidly removed and coronal 
brain slices $(400 \mu \mathrm{m})$ were cut using a vibrating microtome (Microslicer DTK 1500, Dousaka EM Co, Kyoto, Japan) in icecold cutting solution (in mM: 94 sucrose, $30 \mathrm{NaCl}, 4.5 \mathrm{KCl}$, $1 \mathrm{MgCl}_{2}, 26 \mathrm{NaHCO}_{3}, 1.2 \mathrm{NaH}_{2} \mathrm{PO}_{4}$, and $10 \mathrm{D}$-glucose, $\mathrm{pH}$ 7.4) oxygenated with a gas mixture of $95 \% \mathrm{O}_{2} / 5 \% \mathrm{CO}_{2}$. The hippocampal slices were then incubated in ACSF (in mM: 126 $\mathrm{NaCl}, 1 \mathrm{CaCl}_{2}, 2.5 \mathrm{KCl}, 1 \mathrm{MgCl}_{2}, 26 \mathrm{NaHCO}_{3}, 1.25 \mathrm{KH}_{2} \mathrm{PO}_{4}$, and $20 \mathrm{D}$-glucose, $\mathrm{pH} 7.4$ ) oxygenated with a gas mixture of $95 \%$ $\mathrm{O}_{2} / 5 \% \mathrm{CO}_{2}$ at $32-34^{\circ} \mathrm{C}$.

\section{Electrophysiological Analysis}

After $1 \mathrm{~h}$ recovery, the slices were transferred to a recording chamber for whole cell patch-clamp recording. The slice was perfused continually with oxygenated ACSF. The glass pipette (4-5 $\mathrm{M} \Omega$ resistance) was filled with an internal solution (in mM: Cs-gluconate 120, $\mathrm{NaCl} 2, \mathrm{MgCl}_{2}$ 4, $\mathrm{Na}_{2}$-ATP 4, HEPES 10, and EGTA 10) at $\mathrm{pH} 7.2$. Atropine $(0.5 \mathrm{mM})$ was added to the external solution to block muscarinic acetylcholine receptors. In addition, $10 \mu \mathrm{M}$ bicuculline, $20 \mu \mathrm{M}$ AP-5, $10 \mu \mathrm{M}$ NBQX, $0.1 \mu \mathrm{M}$ TTX were applied extracellularly. The holding potential was $-70 \mathrm{mV}$. The $\alpha 7 \mathrm{nAChR}$-activated current $\left(I_{\mathrm{ACh}}\right)$ was induced by the application of ACh using a rapid drug delivery system as described (Colon-Saez and Yakel, 2011; Li et al., 2013) and recorded using an EPC10 amplifier (HEKA Elektronik, Lambrecht/Pfalz, Germany). Peak currents, decay kinetics, and curve fitting were measured and analyzed using Clampfit (Molecular Devices) Origin (OriginLab Corp., Northampton, MA, United States), and Sigmaplot10. The $I_{\mathrm{ACh}}$ was normalized to $I_{\mathrm{ACh}}$ evoked by $3 \mathrm{mM} \mathrm{ACh}$ in the same neuron to produce dose-response curve. The data were fitted to Logistic equation in which $I=I \max /\left[1+\left(\mathrm{EC}_{50} / C\right)^{n}\right]$, with $n$ being Hill coefficient and $\mathrm{EC}_{50}$ being the concentration producing $50 \%$ maximal response. The $\alpha 7 n$ AChRs desensitization was calculated by the half-time of desensitization that was required for $50 \%$ decay of peak $I_{\mathrm{ACh}}$ amplitude (Gay et al., 2008).

\section{Slices Biotinylation}

After $1 \mathrm{~h}$ recovery, the hippocampal slices were washed once for $5 \mathrm{~min}$ in ice-cold ACSF, and then incubated with ACSF containing EZ-link Sulfo-NHS-SS-Biotin $(0.5 \mathrm{mg} / \mathrm{ml}$, Pierce, Northumberland, United Kingdom) on a shaker for $25 \mathrm{~min}$ at $4^{\circ} \mathrm{C}$. To remove excess biotin, slices were washed three times with $50 \mathrm{mM} \mathrm{NH}{ }_{4} \mathrm{Cl}$ in ACSF for $5 \mathrm{~min}$ at $4^{\circ} \mathrm{C}$. The hippocampal tissue was dissected out and homogenized in lysis buffer containing $50 \mathrm{mM}$ Tris- $\mathrm{HCl}$ (pH 7.4), $150 \mathrm{mM} \mathrm{NaCl}$, $1.5 \mathrm{mM} \mathrm{MgCl}_{2}, 1 \mathrm{mM}$ EGTA, $0.5 \mathrm{mM}$ DTT, $50 \mathrm{mM} \mathrm{NaF}$, $2 \mathrm{mM}$ sodium pyruvate, $25 \%$ glycerol, $1 \%$ triton $\mathrm{X}-100,0.5 \%$ sodium deoxycholate, and $1 \%$ protease inhibitor cocktail (Sigma). Following the centrifugation at $20,000 \times g$ for $20 \mathrm{~min}$ at $4^{\circ} \mathrm{C}$, the supernatants were collected as the source of proteins. The protein concentration was determined by Bradford protein assay. The biotinylated proteins $(50 \mu \mathrm{g})$ were incubated with streptavidin-coated magnetic beads $(30 \mu \mathrm{l})$ on a head-over-head shaker for $45 \mathrm{~min}$ at room temperature. The streptavidin beads attaching biotinylated proteins were washed three times with lysis buffer containing $0.1 \%$ SDS, and separated by a magnet.
The biotinylated proteins were eluted in sample buffer $(62.5 \mathrm{mM}$ Tris- $\mathrm{HCl}, 2 \% \mathrm{SDS}, 5 \%$ glycerol, $5 \% 2$-mercaptoethanol) at $100^{\circ} \mathrm{C}$ for $5 \mathrm{~min}$. The protein lysates were also denatured in the same method. The protein lysates (cytoplasmic proteins) and biotinylated proteins (cell surface proteins) were frozen until analysis.

\section{Immunoprecipitation and Western Blot Analysis}

The mice were deeply anesthetized with isoflurane and decapitated. The hippocampus were rapidly removed and homogenized in a lysis buffer containing $50 \mathrm{mM}$ Tris$\mathrm{HCl}(\mathrm{pH}$ 7.5), $150 \mathrm{mM} \mathrm{NaCl}, 5 \mathrm{mM}$ EDTA, $10 \mathrm{mM} \mathrm{NaF}$, $1 \mathrm{mM}$ sodium orthovanadate, $1 \%$ Triton $\mathrm{X}-100,0.5 \%$ sodium deoxycholate, $1 \mathrm{mM}$ phenylmethylsulfonyl fluoride and protease inhibitor cocktail (Complete; Roche, Mannheim, Germany). The incubations were performed for $30 \mathrm{~min}$ at $4^{\circ} \mathrm{C}$ with shaking. Protein concentration was determined with BCA Protein Assay Kit (Pierce Biotechnology Inc., Rockford, IL, United States).

For immunoprecipitation assays, total proteins (500 $\mu \mathrm{g}$ ) were incubated with rabbit anti- $\alpha 7 \mathrm{nAChR}$ antibody $(1: 1000$; Chemicon, CA, United States) overnight at $4^{\circ} \mathrm{C}$. Next, $40 \mu \mathrm{l}$ protein A/G-Sepharose (GE Healthcare, Sweden) was added and the samples were incubated for $1 \mathrm{~h}$ at $4^{\circ} \mathrm{C}$ in a shaker. The immunocomplexes were centrifuged at $4^{\circ} \mathrm{C}$ for $5 \mathrm{~min}$ at $1000 \times \mathrm{g}$ and washed four times with homogenization buffer (ContrerasVallejos et al., 2014). The supernatants were analyzed by Western blotting.

For Western blot, total proteins $(20 \mu \mathrm{g})$ were separated by SDS-polyacrylamide gel electrophoresis (SDS-PAGE) and transferred to a polyvinylidene fluoride (PVDF) membrane. The membranes were incubated with antibodies of rabbit polyclonal anti- $\alpha 7 \mathrm{nAChR}$ (1:1000; Abcam, Cambridge, United Kingdom), anti-phospho-PKA (1:1000; Millipore, MA, United States), antiphospho-PKC (1:1000; Abcam, Cambridge, United Kingdom), anti-phospho-CaMKII (1:1000; Cell Signaling Technology, MA, United States), anti-phospho-Ser (1:1000; Santa Cruz, CA, United States), and anti-phospho-Thr (1:1000; Santa Cruz, CA, United States). After washing, the membranes were incubated with horse radish peroxidase-labeled goat antirabbit antibody (1:5000; Santa Cruz, CA, United States), and developed using the enhanced chemiluminescence detection Kit (Millipore). Following visualization, the blots were stripped by incubation in stripping buffer (Restore; Pierce) for $15 \mathrm{~min}$, and then incubated with antibodies of anti-PKC (1:1000; Abcam), anti-PKA (1:1000; Millipore) and anti-CaMKII (1:1000; Abcam), or anti- $\beta$-actin (1:1000, Cell Signaling Technology). Western blot bands were scanned and analyzed with the image analysis software package (Image J; NIH Image, Bethesda, MD, United States). AMPA receptor subunits glutamic acid receptor 2 (GluR2) was highly expressed in the membrane surface of hippocampal neuronal cells (Mielke and Mealing, 2009). We observed that the treatment of slices with SV $(10 \mu \mathrm{M})$ for 2 or $4 \mathrm{~h}$ had no effect on the AMPA receptor activity (Chen et al., 2016b) and the levels of surface GluR2 protein 
(Figure 2A). Thus, in this study the biotinylated membrane surface $\alpha 7 n A C h R$ protein was normalized by surface GluR2 protein and cytoplasmic $\alpha 7 \mathrm{nAChR}$ protein was normalized by $\beta$-actin.

\section{Data Analysis}

The group data were expressed as the means \pm standard error (SE). All statistical analyses were performed using SPSS software, version 16.0 (SPSS Inc., United States). Differences among means were analyzed using the Student's $t$-tests or analyses of variance (ANOVA) with or without repeated measures, followed by Bonferroni post hoc analysis. Differences at $P<0.05$ were considered statistically significant.

\section{RESULTS}

\section{Effects of SV on $\alpha 7 n A C h R$ Activity in Hippocampal CA1 Pyramidal Cells}

ACh-evoked inward current $\left(I_{\mathrm{ACh}}\right)$ in hippocampal CA1 pyramidal cells was examined using whole cell patch-clamp recording. The $\alpha 7 \mathrm{nAChRs}$ completely recovered from desensitization after washing for 1 min with ACh (ColonSaez and Yakel, 2011). During repeated ejections of ACh (1 mM) at $4 \mathrm{~min}$ intervals, the $I_{\mathrm{ACh}}$ densities remained stable and exhibited no rundown for $30-40 \mathrm{~min}(n=7-8$ cells/4 mice per experimental group; Figure 1A). ACh dose-response curves were constructed to evaluate the response of $\alpha 7 \mathrm{nAChR}$ to different concentrations of ACh (Figure 1B), where $I_{\mathrm{ACh}}$ amplitude displayed a concentration-dependent increase $\left(F_{6,49}=80.407\right.$, $p<0.001$ ).

To investigate the acute effect of SV on $\alpha 7 \mathrm{nAChR}$ activity, hippocampal slices $(400 \mu \mathrm{m})$ were incubated in $0.1-20 \mu \mathrm{M}$ concentrations of SV for $2 \mathrm{~h}$ or treated with $10 \mu \mathrm{M}$ SV for $0.5-4 \mathrm{~h}$. The SV treatment does not alter the intrinsic properties of pyramidal cell membranes (Parent et al., 2014). As shown in Figure 1C, the treatment with SV could increase the amplitude of $I_{\mathrm{ACh}}$ in a dose-dependent manner $\left(F_{4,35}=58.465, p<0.001\right)$. In addition, the $S V$-induced increases in $I_{\mathrm{ACh}}$ amplitude required treatment to last for longer than $90 \mathrm{~min}\left(F_{4,35}=30.806, p<0.001\right.$; Figure 1D).

According to the above results, we examined the influence of SV $(10 \mu \mathrm{M})$-treatment for $2 \mathrm{~h}$ in the sensitivity of $\alpha 7 \mathrm{nAChR}$ to agonists. As shown in Figure 1B, the treatment of SV altered the dose-response curves of $I_{\mathrm{ACh}}\left(F_{6,49}=75.836, p<0.001\right)$. In comparison with controls, the treatment with SV significantly increased the $I_{\mathrm{ACh}}$ amplitude $\left(F_{1,14}=25.035, p<0.001\right)$. The value of $\mathrm{EC}_{50}(124.0 \pm 1.67 \mu \mathrm{M})$ and Hill coefficient (1.50) did not differ significantly from controls $\left(\mathrm{EC}_{50}=117.1 \pm 0.94 \mu \mathrm{M}\right.$; Hill coefficient $=1.44 ; p>0.05$ ). In addition, the SV treatment did not cause the change in the desensitization half-time (ms) of $I_{\mathrm{ACh}}\left(p>0.05\right.$; Figure 1E). The SV-induced increase in $I_{\mathrm{ACh}}$ amplitude was sensitive to the perfusion of $\alpha 7 \mathrm{nAChR}$ antagonist MLA $(10 \mu \mathrm{M})$ for $5 \mathrm{~min}(p<0.01$; Figure 1F). The results show that the treatment with SV $(>1 \mu \mathrm{M})$ for over 90 min can potentiate the $\alpha 7 \mathrm{nAChR}$ activity without changes in the agonist sensitivity and the kinetics of desensitization.

\section{Effects of SV on the Distribution of $\alpha 7$ nAChRs on Hippocampal CA1 Neurons}

The enhanced membrane surface localization of $\alpha 7 \mathrm{nAChR}$ can increase $\alpha 7 n A C h R$ response (Kanno et al., 2012a,b). To assess localization of $\alpha 7 \mathrm{nAChRs}$, we measured the levels of biotinylated $\alpha 7 \mathrm{nAChR}$ protein and cytoplasmic $\alpha 7 \mathrm{nAChR}$ protein in the hippocampus ( $n=6$ mice per experimental group; 3-4 slices/mouse were treated), respectively. Western blot analysis revealed an increase in the level of biotinylated $\alpha 7 \mathrm{nAChR}$ protein that was dependent on the concentrations of SV $(0.1-20 \mu \mathrm{M})$ $\left(F_{4,25}=7.607, p<0.001\right.$; Figure $\left.2 \mathrm{~A}\right)$, which was associated with a dose-dependent decrease in the level of cytoplasmic $\alpha 7 \mathrm{nAChR}$ protein $\left(F_{4,25}=3.869, p=0.014\right.$; Figure $\left.2 \mathrm{~B}\right)$. By contrast, the levels of non-biotinylated membrane (Figure 2C) and total $\alpha 7 \mathrm{nAChR}$ protein were not altered by the treatment with SV $\left(F_{4,25}=0.516, p=0.724\right.$; Figure 2D). The results show that the treatment with $\mathrm{SV}$ is able to enhance the trafficking of $\alpha 7 n A C h R$.

\section{Involvement of SV-Reduced Isoprenoids in $\alpha 7 \mathrm{nAChR}$ Activity and Trafficking}

To test whether SV enhances $\alpha 7 n A C h R$ activity and trafficking through the reduction of isoprenoids FPP and GGPP (Eckert et al., 2009), the hippocampal slices were co-treated with SV $(10 \mu \mathrm{M})$ and farnesol $(\mathrm{FOH}, 2 \mu \mathrm{M})$ or geranylgeraniol (GGOH, $2 \mu \mathrm{M}$ ), which convert FPP and GGPP, for $2 \mathrm{~h}$. The addition of FOH partially reduced the SV-increased $I_{\mathrm{ACh}}(p<0.05, n=8$ cells/4 mice; Figure $3 \mathrm{~A}$ ), but failed to alter basal amplitude of $I_{\mathrm{ACh}}$ in control slices ( $p>0.05, n=8$ cells $/ 4$ mice). By contrast, the application of GGOH had no effects on the basal amplitude of $I_{\mathrm{ACh}}$ and the SV-increased $I_{\mathrm{ACh}}(p>0.05, n=8$ cells/4 mice). Notably, the SV-increased biotinylated $\alpha 7 \mathrm{nAChR}$ protein ( $p<0.01, n=6$ mice, $3-4$ slices/mouse; Figure 3C) and SV-decreased cytoplasmic $\alpha 7 n A C h R$ protein $(p<0.05, n=6$ mice; Figure 3D) were blocked by the addition of FOH, but not GGOH ( $p>0.05, n=6$ mice).

The farnesylation of small GTPases is catalyzed by farnesyl transferase. To further determine whether the treatment with SV by the inhibition of farnesylation enhances the $\alpha 7 \mathrm{nAChR}$ activity and trafficking, we examined the effects of the farnesyl transferase inhibitor FTI277 (FTI) on the $\alpha 7$ nAChR activity and trafficking. As expected, the treatment with FTI $(1 \mu \mathrm{M})$ for $2 \mathrm{~h}$ significantly increased $I_{\mathrm{ACh}}$ amplitude $(p<0.05, n=8$ cells/4 mice; Figure 3B) in a MLA-sensitive manner $(p<0.01$, $n=8$ cells $/ 4$ mice). Interestingly, the FTI-increased $I_{\mathrm{ACh}}$ was further enlarged by the addition of SV ( $p<0.05, n=8$ cells $/ 4$ mice), although it was not affected by the addition of $\mathrm{FOH}$ ( $p>0.05, n=8$ cells $/ 4$ mice). Similarly, the treatment with FTI increased the level of biotinylated $\alpha 7 \mathrm{nAChR}$ protein $(p<0.01$, $n=6$ mice) with a concurrent decrease in cytoplasmic $\alpha 7 \mathrm{nAChR}$ protein $(p<0.05, n=6$ mice). However, these parameters were not affected by the addition of SV $(p>0.05, n=6$ mice) or FOH ( $p>0.05, n=6$ mice). These results indicate that SV through suppressing farnesylation of small GTPases enhances $\alpha 7 \mathrm{nAChR}$ activity and surface localization, whereas the 
A

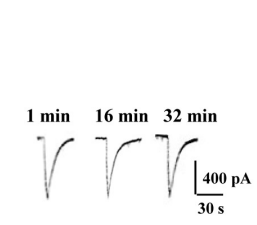

B
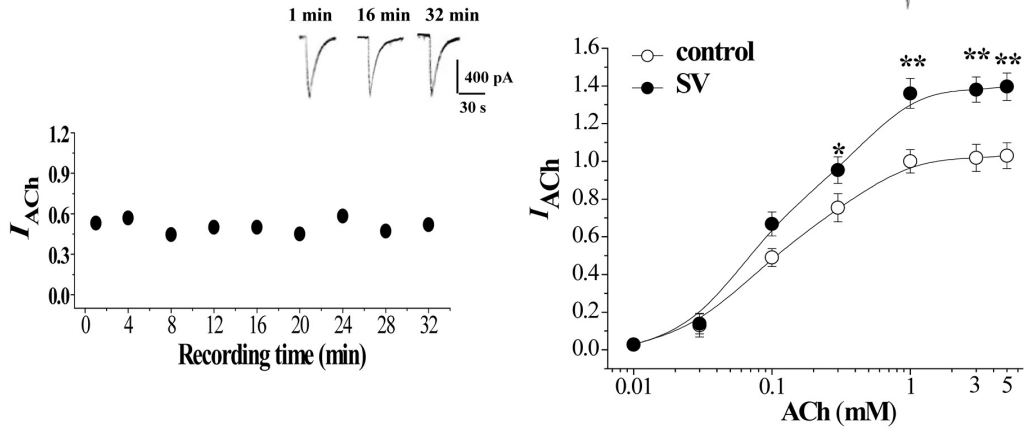

C
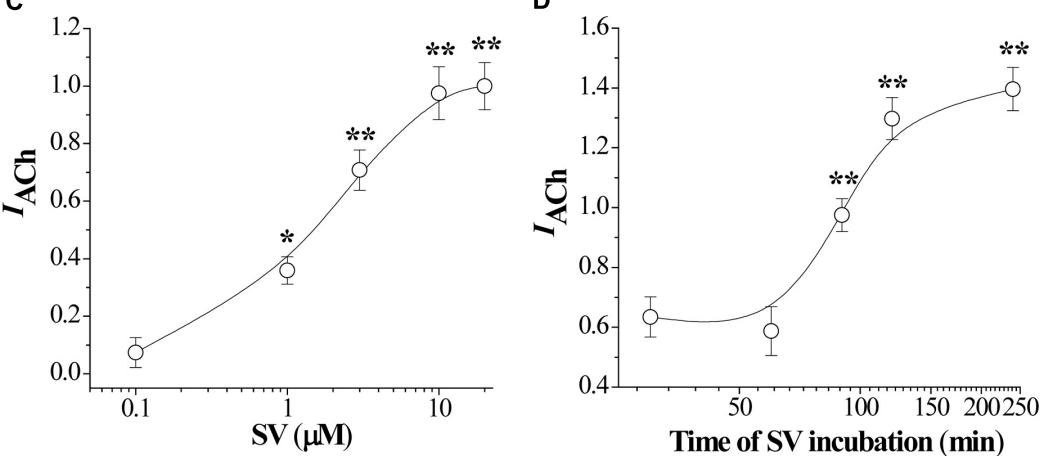

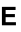

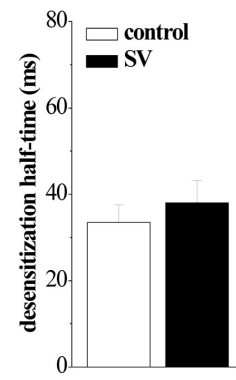

$\mathbf{F}$

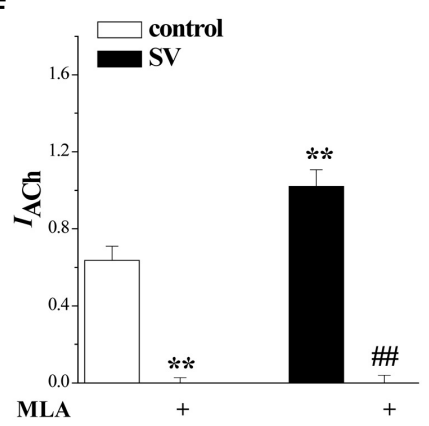

FIGURE 1 | Acute treatment with Simvastatin enhances $\alpha 7 n A C h R$ activity in hippocampal CA1 pyramidal cells. (A) Repeated applications of ACh (1.0 mM) with 4 min interval evoke whole cell currents $\left(I_{\text {ACh }}\right)$. Representative traces of $I_{A C h}$ evoked at the time of 1, 16, and 32 min. (B) The CA1 pyramidal cells were subjected to consecutive $1 \mathrm{sec}$ applications of $0.01,0.03,0.1,0.3,1,3$, and $5 \mathrm{mM}$ ACh. Dose-response curves were constructed by the amplitude of $I_{\mathrm{ACh}}$ (means $\pm \mathrm{SEM}$ ) that were normalized by a control value evoked by ACh $(3 \mathrm{mM})$. Representative traces of $I_{\text {ACh }}$ evoked by $1 \mathrm{mM} \mathrm{ACh} .{ }^{*} P<0.05$ and ${ }^{* *} P<0.01$ vs. control slices (repeated-measure ANOVA). (C) Evoked $I_{\text {ACh }}$ by ACh (1 mM) in the slices treated with SV at 0.1, 1, 3, 10, and $20 \mu \mathrm{M}$ for $2 \mathrm{~h}$. Dose-response curves were constructed by the amplitude of $I_{\text {ACh }}$ (means \pm SEM) that were normalized by the treatment with $10 \mu \mathrm{M} \mathrm{SV}$. ${ }^{*} p<0.05$ and ${ }^{* *} p<0.01 \mathrm{vs}$. vehicle-treated control (repeated-measure ANOVA). (D) Evoked I ACh by ACh (1 mM) in the slices treated with SV (10 $\mu \mathrm{M})$ for 30, 60, 90, 120, and 240 min. Time-dependent curves were constructed by the amplitude of $I_{A C h}$ (means $\pm S E M$ ). ${ }^{* *} p<0.01$ vs. vehicle-treated control (repeated-measure ANOVA). (E) Influence of SV treatment (10 $\mu M, 2 \mathrm{~h}$ ) on the desensitization half-time of $\alpha 7 n A C h R$. (F) Sensitivity of evoked $I_{\text {ACh }}$ to $\alpha 7 n A C h R$ antagonist MLA. Mean percent reduction in the amplitude of $I_{\text {ACh }}$ evoked by ACh (1 mM) following application of MLA (10 $\mu$ M) in control slices and SV-treated slices. ${ }^{* *} p<0.01$ vs. control slices; ${ }^{\# \# ~} p<0.01$ vs. SV-treated slices (two-way ANOVA).

enhancing effect of FTI on $\alpha 7 \mathrm{nAChR}$ activity is weaker than that of SV.

\section{Effects of SV on PKA, PKC, and CaMKII Phosphorylation}

A large body of evidence indicates that farnesylation status of small GTPases alters their interactions with intracellular molecules to regulate downstream effectors including PKC, PKA, and CaMKII (McTaggart, 2006). Therefore, we examined the effects of SV $(10 \mu \mathrm{M})$ and FTI $(1 \mu \mathrm{M})$ on the phosphorylation of PKC $\varepsilon$ (phospho-PKC $\varepsilon$ ), CaMKII (phospho-CaMKII), and PKA (phospho-PKA) $(n=6$ mice per experimental group, 2 slices/mouse were treated). Notably, the treatment with SV elevated the levels of phospho-PKCE $(p<0.01$; Figure 4A) and phospho-CaMKII ( $p<0.01$; Figure $4 \mathrm{C}$ ), but not phospho-PKA 
A
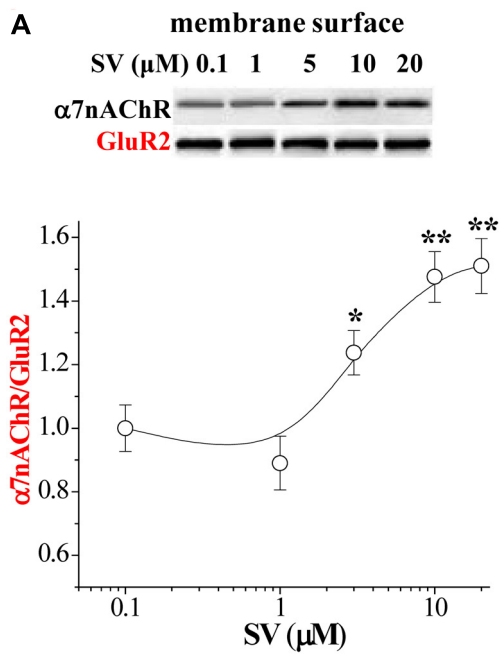

C

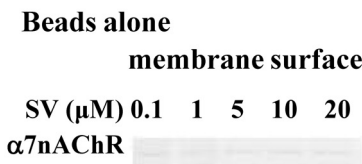

GluR2
B cytoplasm

$\mathrm{SV}(\mu \mathrm{M}) \begin{array}{lllll}0.1 & 1 & 5 & 10 & 20\end{array}$

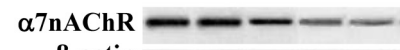

$\beta$-actin

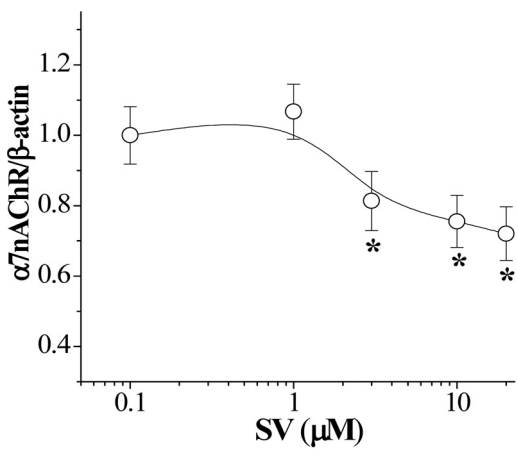

D
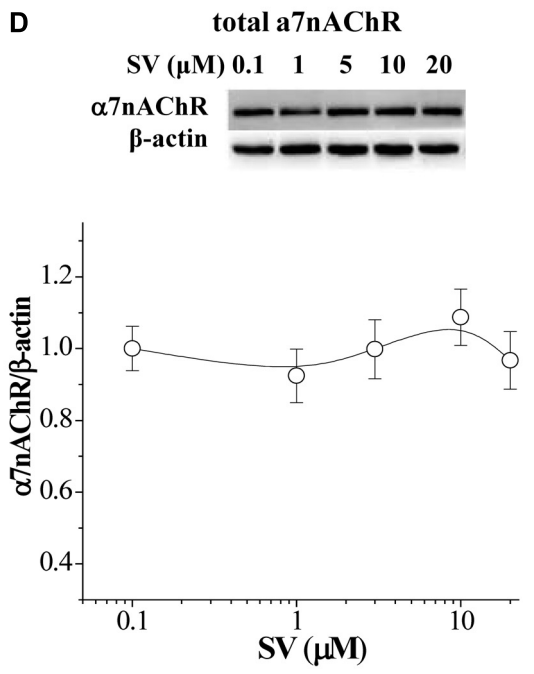

FIGURE 2 | Acute treatment of SV enhances the trafficking of $\alpha$ 7nAChR. (A,B) Representative Western blots of cell membrane surface (surface) and cytoplasmic $\alpha 7 \mathrm{nAChR}$ protein in hippocampus. Biotin/beads: biotinylated samples. Graphs indicate the mean levels of surface $\alpha 7 \mathrm{nAChR}$ (A) and cytoplasmic $\alpha 7 \mathrm{nAChR}$ (B) in control and SV-treated hippocampus. Surface $\alpha 7 \mathrm{nAChR}$ was normalized by surface GluR2 protein and cytoplasmic $\alpha 7 \mathrm{nAChR}$ was normalized by $\beta$-actin, which was again normalized by vehicle-treated group. ${ }^{*} p<0.05$ and ${ }^{* *} p<0.01$ vs. control slices (two-way ANOVA). (C) "Beads alone" indicates non-biotinylated samples as a negative control. (D) Total $\alpha 7 \mathrm{nAChR}$ protein was normalized by $\beta$-actin, which was again normalized by vehicle-treated group.

$(p>0.05$; Figure 4B). The SV-increased phospho-CaMKII $(p<0.01)$, but not phospho-PKCE $(p>0.05)$, was blocked by the treatment with $\mathrm{FOH}$ for $2 \mathrm{~h}$. Interestingly, the treatment with FTI increased the level of phospho-CaMKII $(p<0.01)$ and failed to alter the level of phospho-PKA $(p>0.05)$. Although the FTI treatment had a tendency to reduce the phospho-PKC $\varepsilon$, the difference was not significant compared to the control slices $(p>0.05)$. The addition of the Src inhibitor PP2 $(10 \mu \mathrm{M})$ or the NMDAr antagonist MK801 $(10 \mu \mathrm{M})$ for $2 \mathrm{~h}$ abolished the SV- and FTI-induced increases in phosphoCaMKII $(p<0.01)$. However, the SV-increased phospho-PKC $\varepsilon$ was insensitive to PP2 $(P>0.05)$, MK801 $(P>0.05)$. Notably, the IP3R blocker 2-APB $(75 \mu \mathrm{M})$ could partially prevent the SV-increased phospho-PKCE $(P<0.05)$. The co-treatment with the PKC inhibitor GF109203X (100 nM) failed to alter the
SV-increased phospho-CaMKII $(p>0.05)$. The $2 \mathrm{~h}$ treatment with the PKC activator PMA (100 nM) had no effect on the phospho-CaMKII $(p>0.05)$. These results indicate that SV triggers the Src/NMDAr-dependent CaMKII signaling pathway through suppressing farnesylation of small GTPases. Meanwhile, the SV-increased phospho-PKCE was not associated with a decrease in FPP.

\section{Involvement of PKC/CaMKII in SV-Increased $\alpha 7 n A C h R$ Activity and Trafficking}

The activity of $\alpha 7 \mathrm{nAChR}$ is regulated by the PKC and CaMKII signaling pathways (Komal et al., 2015). To test the possibility, the hippocampal slices were co-treated with SV and the PKC 
A

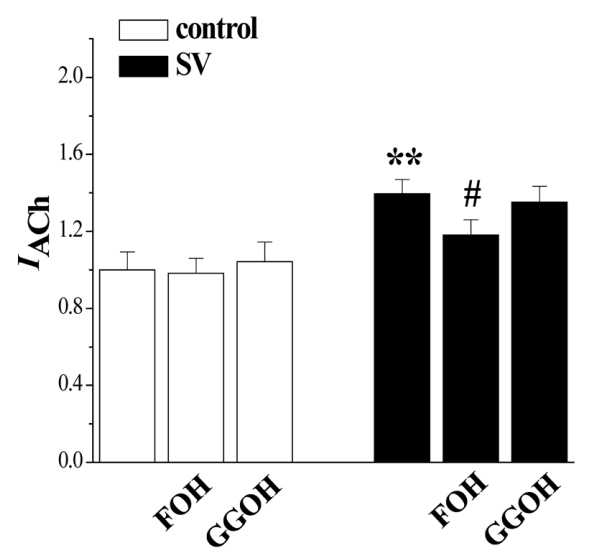

C

membrane surface
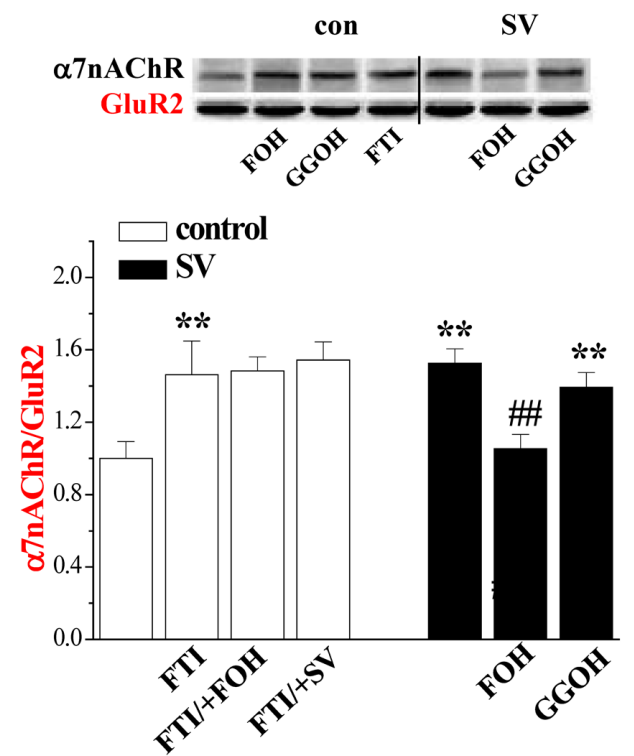

B

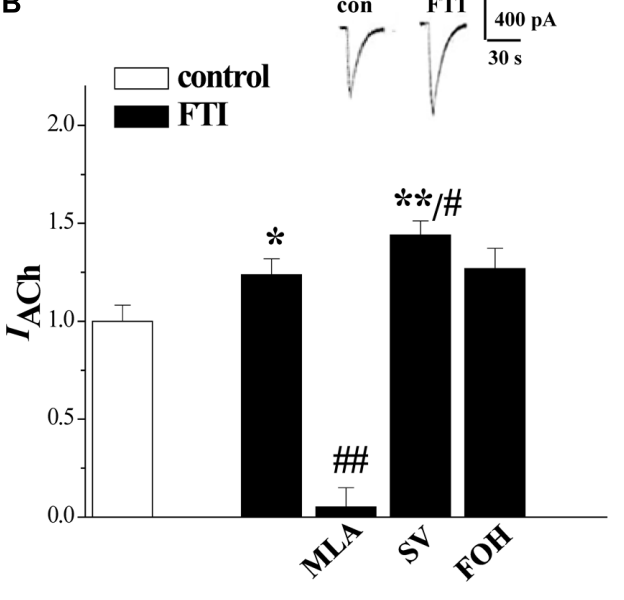

D

cytoplasm
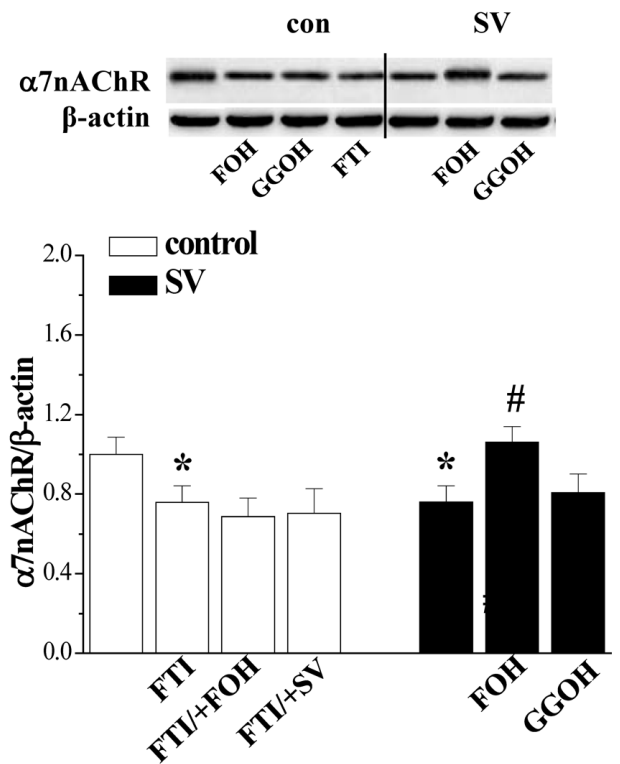

FIGURE 3 | Simvastatin through reducing FPP enhances $\alpha 7 n A C h R$ activity and trafficking. (A) Effects of FOH or GGOH addition in SV-enhanced $\alpha 7 n A C h R$ activity. Bars show the amplitude of $I_{A C h}$ in control slices, SV-treated slices, $S V /+F O H$ - and SV/+GGOH-treated slices. ${ }^{* *} p<0.01$ vs. control slices and ${ }^{\#} p<0.05$ vs. SV-treated slices (two-way ANOVA). (B) Effects of FTI on $\alpha 7 n A C h R$ activity in hippocampal CA1 pyramidal cells. Bars show the amplitude of $I_{A C h}$ in FTI/+MLA-, $\mathrm{FTl} /+$ SV- and FTI/+FOH-treated slices. ${ }^{*} p<0.05$ and ${ }^{* *} p<0.01$ vs. control slices and ${ }^{\#} p<0.05$ and ${ }^{\# \#} p<0.01$ vs. FTI-treated slices (two-way ANOVA). (C,D) Effects of FOH or GGOH addition in SV-enhanced $\alpha 7 n A C h R$ trafficking. Bar graphs show the levels of biotinylated $\alpha 7 n A C h R$ protein and cytoplasmic $\alpha 7 n A C h R$ protein in control slices, $\mathrm{FTI}$-treated slices, $\mathrm{FTI} /+\mathrm{FOH}$ - and $\mathrm{FTI} /+\mathrm{SV}$-treated slices, SV/+FOH- or SV/+GGOH-treated slices. Surface $\alpha 7 \mathrm{nAChR}$ was normalized by surface GluR2 protein and cytoplasmic $\alpha 7$ ACChR was normalized by $\beta$-actin. ${ }^{*} p<0.05$ and ${ }^{* *} p<0.01$ vs. control slices. ${ }^{\#} p<0.05$ and ${ }^{\# \#} p<0.01$ vs. SV-treated slices (two-way ANOVA).

inhibitors GF1092203X and Go6983 (10 nM) or the CaMKII inhibitor KN93 $(3 \mu \mathrm{M})$. Interestingly, the treatment with either GF1092203X $(P<0.05, n=8$ cells/4 mice; Figure 5A $)$ and Go6983 $(P<0.05, n=8$ cells $/ 4$ mice $)$ or $\mathrm{KN} 93(P<0.05$, $n=8$ cells $/ 4$ mice) partially suppressed the SV-increased $I_{\mathrm{ACh}}$ amplitude. By contrast, the SV-increased biotinylated $\alpha 7 \mathrm{nAChR}$ protein was blocked by the addition of KN93 $(P<0.01, n=6$ mice; Figure 5B), but not GF1092203X $(P>0.05, n=6$ mice) or Go6983 ( $P>0.05, n=6$ mice). In addition, the
FTI-increased $I_{\mathrm{ACh}}$ amplitude $(P<0.05, n=8$ cells $/ 4$ mice $)$ and biotinylated $\alpha 7 \mathrm{nAChR}$ protein $(P<0.01, n=6$ mice $)$ were completely blocked by the addition of KN93. The addition of GF1092203X or Go6983 had no effect on the FTI-increased $I_{\mathrm{ACh}}$ $(P>0.05, n=8$ cells $/ 4$ mice $)$ and biotinylated $\alpha 7 \mathrm{nAChR}$ protein $(P>0.05, n=6$ mice). In control slices, the PKC activation by PMA increased $I_{\mathrm{ACh}}$ amplitude $(P<0.01, n=8$ cells $/$ 4 mice), but failed to alter the level of biotinylated $\alpha 7 \mathrm{nAChR}$ protein $(P>0.05, n=6$ mice). Furthermore, the application 


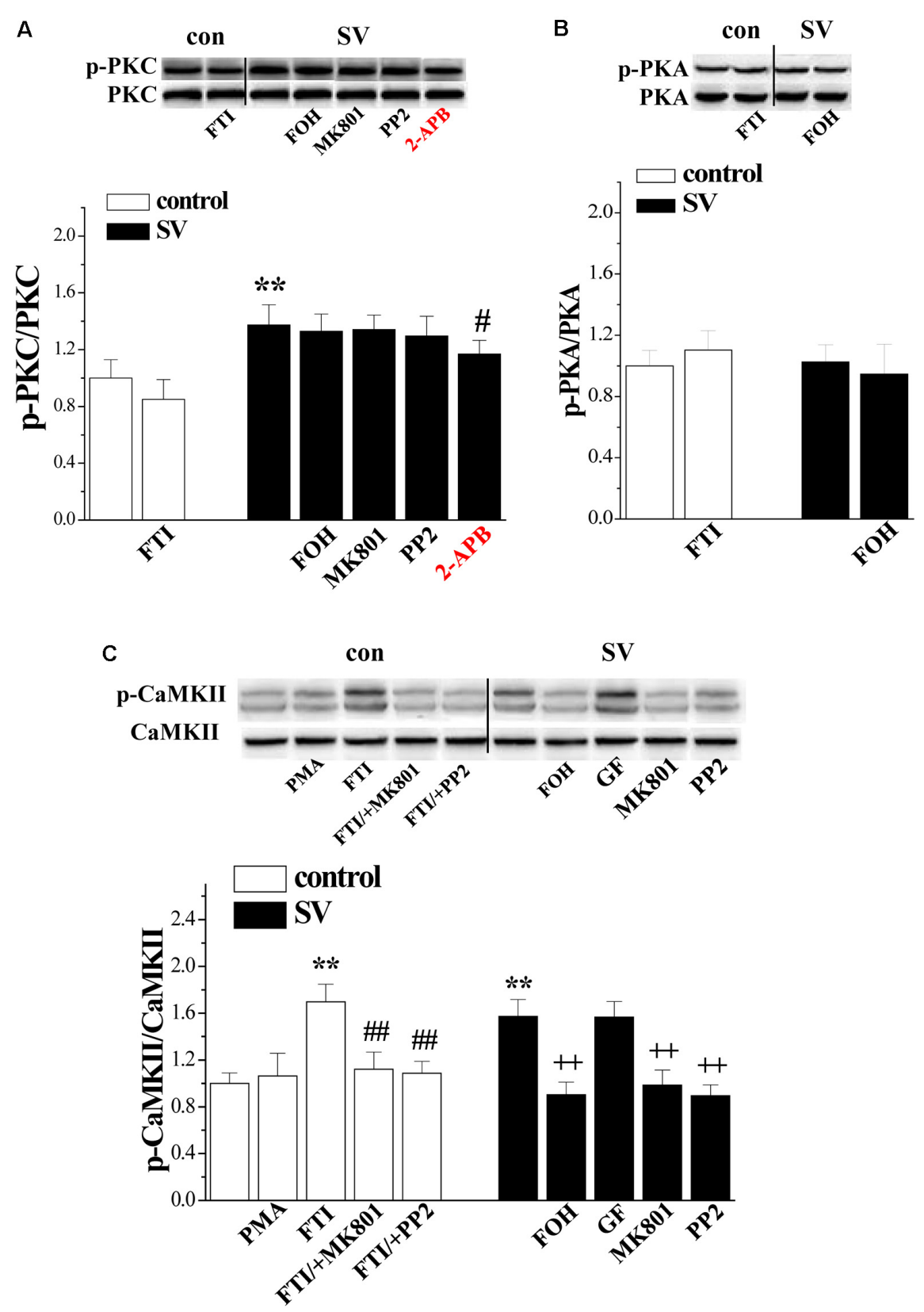

FIGURE 4 | Simvastatin cascades PKC and CaMKIl signaling pathways. (A) Bar graphs show the levels of phospho-PKC in FTI-treated slices, SV/+FOH-, SV/+MK801-, SV/+PP2- and SV/+2-APB-treated slices. ${ }^{* *} p<0.01$ vs. control slices; ${ }^{\#} p<0.05$ vs. SV-treated slices. (B) Bar graphs show the levels of phospho-PKA in FTI-treated slices, SV/+FOH-treated slices. (C) Bars represent the levels of phospho-CaMKII in PMA- or FTI-treated slices, FTI/+MK801- or FTI/+PP2-treated slices, SV/+FOH-, SV/+GF-, SV/+MK801- and SV/+PP2-treated slices. ${ }^{*} P<0.01$ vs. control slices; ${ }^{\# \#} p<0.01$ vs. FTI-treated slices; $++p<0.01$ vs. SV-treated slices (two-way ANOVA).

of GF1092203X alone had no effects on the $I_{\mathrm{ACh}}$ amplitude $(P>0.05, n=8$ cells $/ 4$ mice $)$ or the biotinylated $\alpha 7 \mathrm{nAChR}$ protein $(P>0.05, n=6$ mice). These results indicate that SVincreased $\alpha 7$ nAChR activity depends on the activation of PKC and CaMKII, while SV- and FTI-increased $\alpha 7 \mathrm{nAChR}$ trafficking are CaMKII-dependent.

Serine 365 in the M3-M4 cytoplasmic loop of the $\alpha 7 \mathrm{nAChR}$ is a phosphorylation site for PKA (Moss et al., 1996).
Phosphorylation of $\alpha 7 \mathrm{nAChR}$ by PKC modulates the receptor channels (Huganir and Greengard, 1990). Based on this, we examined the phosphorylation of $\alpha 7 \mathrm{nAChR}$ (phospho$\alpha 7 \mathrm{nAChR}$ ) ( $n=6$ mice). The results showed that the treatment with SV $(10 \mu \mathrm{M})$ or FTI $(1 \mu \mathrm{M})$ for $2 \mathrm{~h}$ failed to alter the levels of phospho- $\alpha 7 n A C h R(p>0.05$; Figure $5 C$ ). In addition, the treatment with GF109203X, PMA or KN93 did not affect the level of phospho- $\alpha 7 \mathrm{nAChR}(p>0.05)$. 

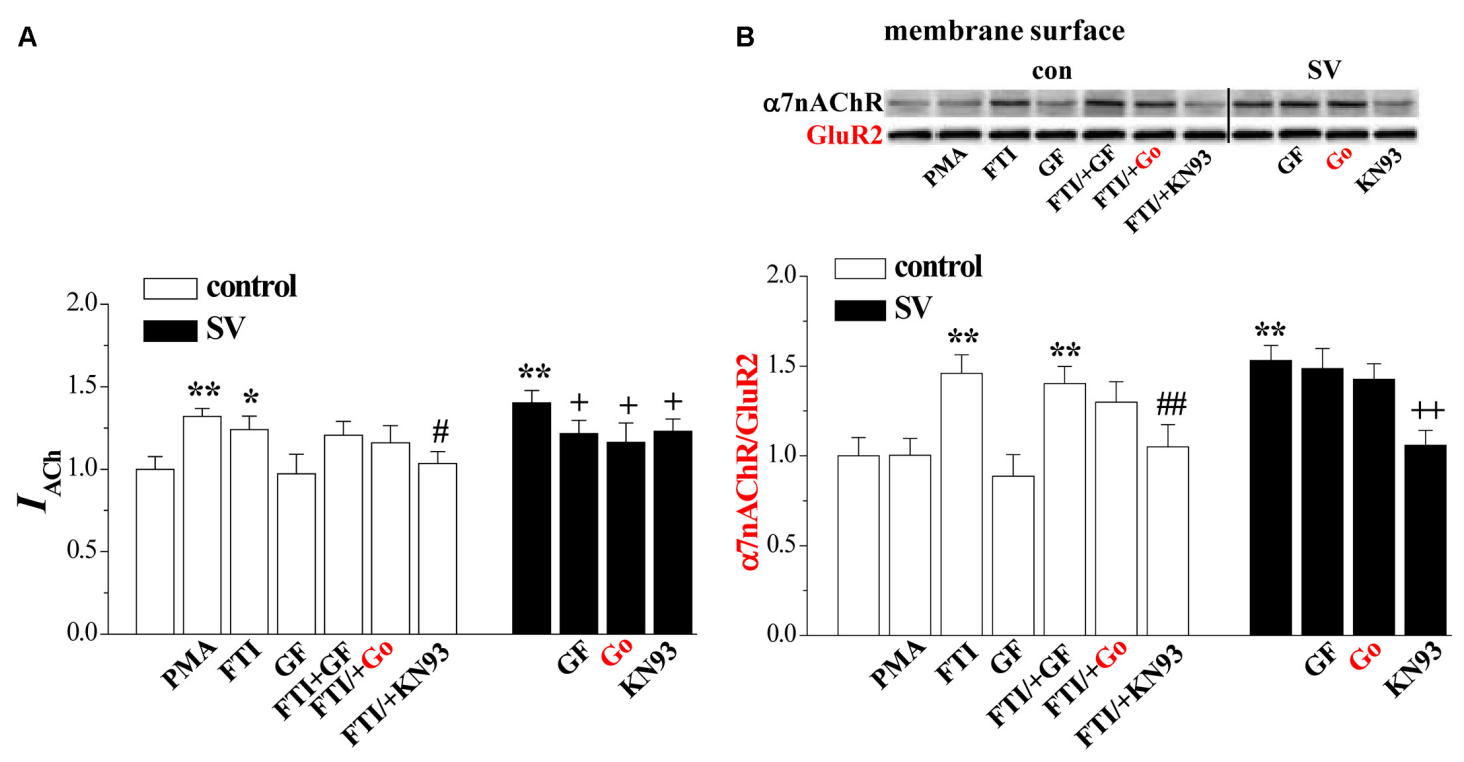

C

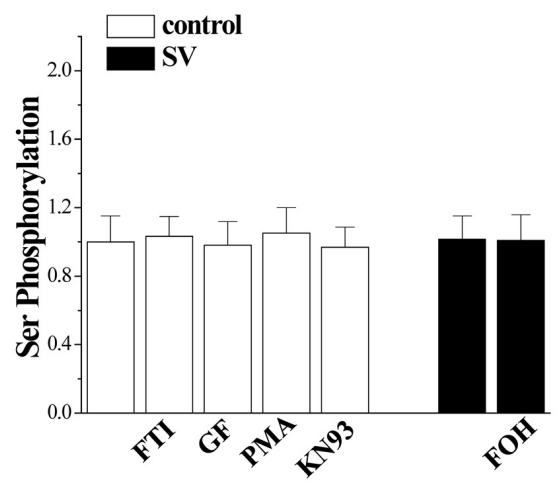

FIGURE 5 | Involvement of PKC and CaMKII signlaing pathways in SV-enhanced $\alpha 7$ nAChR activity and trafficking. (A,B) Bar graphs show the amplitude of $I_{\text {ACh }}$ and the levels of biotinylated $\alpha 7 n A C h R$ protein in PMA-, GF- or FTI-treated slices, FTI/+GF-, FTI/+Go- or FTI/+KN93-treated slices, SV/+GF-, SV/+Go- or SV/+KN93-treated slices. ${ }^{*} p<0.05$ and ${ }^{* *} p<0.01$ vs. control slices; ${ }^{\#} p<0.05$ and ${ }^{\# \#} p<0.01$ vs. FTI-treated slices; ${ }^{+} p<0.05$ and ${ }^{++} p<0.01$ vs. SV-treated slices (two-way ANOVA). (C) Bars indicate the levels of phospho- $\alpha$ 7nAChR in FTI-, GF-, PMA- or KN93-treated slices, SV/+FOH-treated slices.

\section{DISCUSSION}

The principal findings of this present study were that the acute treatment of hippocampal slices with SV enhanced the activity and trafficking of $\alpha 7 \mathrm{nAChRs}$ on CA1 pyramidal cells. This conclusion is based on the following observations. (1) Treatment with SV induced a dose-dependent increase in $I_{A C h}$ amplitude. (2) SV treatment caused a dose-dependent increase in $\alpha 7 \mathrm{nAChR}$ protein on the cell membrane with a decrease in cytoplasmic $\alpha 7 \mathrm{nAChR}$ protein level. (3) Removal of cholesterol and sphingomyelin from lipid rafts through acute cotreatment with statins and myriocin can slow the desensitization kinetics and increase the agonist affinity for $\alpha 7 \mathrm{nAChR}$ (Colon-Saez and Yakel, 2011). The treatment with SV for $2 \mathrm{~h}$ did not alter the half-time (ms) of $\alpha 7 \mathrm{nAChR}$ desensitization. The SV treatment increased the level of maximal $\alpha 7 \mathrm{nAChR}$ response without the changes in $\mathrm{EC}_{50}$ and Hill coefficient of dose-response curve. The findings suggest that the SV treatment did not alter the affinity of $\alpha 7 n A C h R$. (4) The phosphorylation status of $\alpha 7 n A C h R$ was not altered by treatment with SV.

Lovastatin is reported to be an inhibitor of Ras farnesylation (Laezza et al., 2008). Statin therapy causes a decrease in the isoprenoid FPP levels (Eckert et al., 2009). The SV-induced increase in $I_{\mathrm{ACh}}$ amplitude and trafficking of $\alpha 7 \mathrm{nAChRs}$ were suppressed by the addition of FOH to increase the level of FPP. FPP is essential for the Ras farnesylation, a process catalyzed by prenyltransferase farnesyl transferase (Kho et al., 2004). Indeed, the treatment of FTI could increase the amplitude of $I_{\mathrm{ACh}}$, which was insensitive to $\mathrm{FOH}$. The increase in $I_{\mathrm{ACh}}$ amplitude due to FTI treatment was further elevated by the addition of SV. Furthermore, the FTI treatment caused an increase in $\alpha 7 \mathrm{nAChR}$ protein levels in the cellular membrane with a concurrent decrease in the cytoplasmic $\alpha 7 \mathrm{nAChR}$ protein levels. The FTI-enhanced $\alpha 7 n$ AChR trafficking was not affected by the addition of SV or FOH. Like treatment with SV, the $\alpha 7 \mathrm{nAChR}$ phosphorylation was not altered by the treatment 
with FTI. Therefore, it is highly likely that SV by reducing FPP suppresses the Ras farnesylation, which enhances the $\alpha 7 \mathrm{nAChR}$ trafficking leading to the increase in $\alpha 7 \mathrm{nAChR}$ activity.

The treatment of SV or FTI can enhance GluN2B and GluN2A phosphorylation via increasing Src phosphorylation (Chen et al., 2016b). We in this study observed that the SV treatment enhanced phosphorylation of CaMKII, which was blocked by the addition of FOH and mimicked by the FTI application. Moreover, SV- and FTI-enhanced phosphorylation of CaMKII was sensitive to the Src inhibitor PP2 or NMDAr antagonist MK801. Tyrosine phosphorylation of the NMDAr GluN2B and GluN2A subunits and NMDAr activity are higher in the hippocampus of H-Ras null mice than wild type mice (Manabe et al., 2000). Thus, it is conceivable that the treatment with SV via inhibition of Ras farnesylation enhances the $\mathrm{Ca}^{2+}$ influx of NMDAr leading to an increase in the CaMKII phosphorylation. There are conflicting reports describing that the CaMKII signaling is a possible upstream activator of Ras, because after NMDAr channels open CaMKII becomes activated briefly prior to Ras activation (Yasuda et al., 2006; Lee et al., 2009). Moreover, there is opposite results showing that the CaMKII phosphorylation inhibits the Ras activity (Chen et al., 1998). PKC potentiates NMDAr gating to enhance $\mathrm{Ca}^{2+}$ influx, which induces the CaMKII autophosphorylation (Wang and Kelly, 1995; Yan et al., 2011). However, our results did not support the idea, since the PKC inhibitors GF109203X and Go6983 failed to affect the SV- and FTI-enhanced phosphorylation of CaMKII.

The SV- and FTI-induced increases in biotinylated $\alpha 7 \mathrm{nAChR}$ protein were blocked by the CaMKII inhibitor, the Src inhibitor or NMDAr antagonist. The inhibition of CaMKII abolished the FTI-increased $\alpha 7 \mathrm{nAChR}$ activity, but partially prevented the SVincreased $\alpha 7 \mathrm{nAChR}$ activity. The results give an indication that SV and FTI via elevation of CaMKII phosphorylation enhances the $\alpha 7 \mathrm{nAChR}$ trafficking. Responses of $\alpha 7 \mathrm{nAChRs}$ are enhanced by activating CaMKII (Kanno et al., 2012a) through stimulating $\alpha 7 \mathrm{nAChR}$ trafficking or increasing receptor localization in the membrane (Derkach et al., 1999; Malinow and Malenka, 2002). Src family kinase has been reported to directly interact with the cytoplasmic loop of $\alpha 7 \mathrm{nAChR}$ and phosphorylates the receptors at the membrane. The Src inhibition by PP2 increases

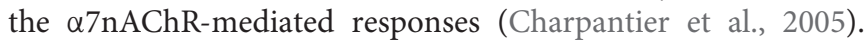
Moreover, the tyrosine kinase inhibitor genistein causes the rapid delivery of $\alpha 7 \mathrm{nAChR}$ to the membrane, which is not accompanied by detectable changes in receptor open probability (Cho et al., 2005).

Another critical finding in this study is that the phosphorylation of PKC was increased by the SV treatment, but this effect of SV was insensitive to the addition of $\mathrm{FOH}$. The most common H-Ras mutation causes an irreversible decrease in PKC activity (Colapietro et al., 1993). PKCE is upregulated by oncogenic Ras activation (Dann et al., 2014). Similarly, the suppressed farnesylation of small GTPases by FTI had a tendency to reduce the PKC $\varepsilon$ phosphorylation. There is a potent activation of the kinase domain of PKC $\delta$ in response to atorvastatin in promyelocytic leukemia cells (Sassano et al.,
2012). Acute treatment with atorvastatin has been reported to promote the $\mathrm{Ca}^{2+}$-mediated PKC activation (Pierno et al., 2009) through a mechanism involving release of $\mathrm{Ca}^{2+}$ from mitochondria and sarcoplasmic reticulum (Liantonio et al., 2007). Indeed, the SV-increased phospho-PKCE was partially prevented by the blocked of IP3R, rather than the NMDAr antagonist or the inhibition of Src. Further experiments are required to explore the mechanisms underlying SV-enhanced PKC phosphorylation.

Several studies provide evidence to support the enhancing effects of PKC $\varepsilon$ on the $\alpha 7 \mathrm{nAChR}$ activity (Miyamoto et al., 2003; Yamamoto et al., 2005). Although the $\alpha 7 n$ AChRs do not contain PKC phosphorylation sites (Moss et al., 1996), the activation of PKC potentiates activity of $\alpha 7 \mathrm{nAChRs} \mathrm{(Nishizaki}$ and Sumikawa, 1997). We observed that the PKC activator PMA increased $\alpha 7 \mathrm{nAChR}$ activity, but had no effect on trafficking of $\alpha 7 \mathrm{nAChR}$. The SV-induced increase in $I_{\mathrm{ACh}}$ amplitude was reduced by a PKC inhibitor. The activation of PKC$\varepsilon$ in the brain potentiates $\alpha 7 \mathrm{nAChRs}$ responses to stimulate presynaptic glutamate release (Kanno et al., 2012c). Activation of PKC can enhance $\alpha 7 \mathrm{nAChR}$ activity by increasing membrane surface localization of the receptor (Kanno et al., 2012b). However, we observed that SV- and FTI-increased $\alpha 7 \mathrm{nAChR}$ trafficking are $\mathrm{PKC}$-independent. Interestingly, we found that the treatment with SV at concentration of $1 \mu \mathrm{M}$ could increase the $I_{\mathrm{ACh}}$ amplitude, while $5 \mu \mathrm{M}$ SV was required for observable enhancement of $\alpha 7 \mathrm{nAChR}$ trafficking. Overall, there are two possible mechanisms underlying the SV-increased $\alpha 7 \mathrm{nAChR}$ activity, which are summarized in Figure 6. One is that SV through reduced FPP and Ras farnesylation can elevate the Src phosphorylation leading to increase in the $\mathrm{Ca}^{2+}$ influx of NMDAr, which enhances the $\alpha 7 \mathrm{nAChR}$ trafficking via increasing CaMKII activity. The other is that SV through enhanced probably IP3R-mediated release of $\mathrm{Ca}^{2+}$ causes an increase in the PKC phosphorylation, which potentiates the $\alpha 7 \mathrm{nAChR}$ activity.

Several studies have reported the reduction and dysfunction of $\alpha 7 \mathrm{nAChRs}$ in the brains of $\mathrm{AD}$ patients

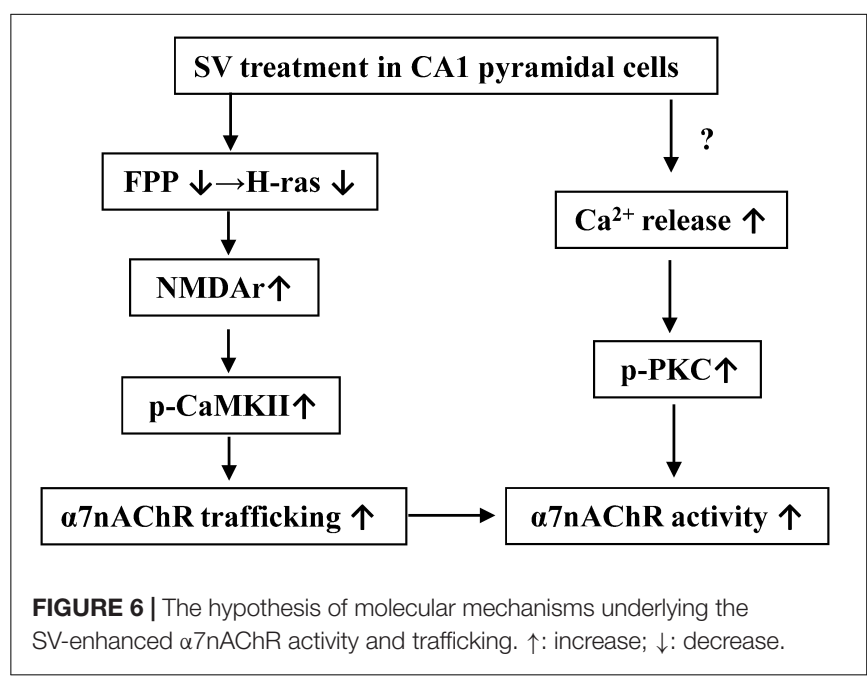


(Kihara et al., 2004; Barrantes et al., 2010). Agonists of $\alpha 7 \mathrm{nAChR}$ have been demonstrated to have beneficial effects on cognitive disorders in AD patients (Ren et al., 2007). Although the mechanism underlying SV-enhanced $\alpha 7 \mathrm{nAChR}$ activity is not completely understood, these results in the present study can help in understanding the anti-dementia effects of treatment with statins in $\mathrm{AD}$ patients.

\section{AUTHOR CONTRIBUTIONS}

TC and LeC performed the electrophysiological experiments and all statistical analyes. YW and TZ undertook the

\section{REFERENCES}

Barrantes, F. J., Borroni, V., and Valles, S. (2010). Neuronal nicotinic acetylcholine receptor-cholesterol crosstalk in Alzheimer's disease. FEBS Lett. 584, 1856-1863. doi: 10.1016/j.febslet.2009.11.036

Burghaus, L., Schutz, U., Krempel, U., de Vos, R. A., Jansen Steur, E. N., Wevers, A., et al. (2000). Quantitative assessment of nicotinic acetylcholine receptor proteins in the cerebral cortex of Alzheimer patients. Brain Res. Mol. Brain Res. 76, 385-388. doi: 10.1016/S0169-328X(00)00 031-0

Charpantier, E., Wiesner, A., Huh, K. H., Ogier, R., Hoda, J. C., Allaman, G., et al. (2005). a7 neuronal nicotinic acetylcholine receptors are negatively regulated by tyrosine phosphorylation and Src-family kinases. J. Neurosci. 25, 9836-9849. doi: 10.1523/JNEUROSCI.3497-05. 2005

Chen, H. J., Rojas-Soto, M., Oguni, A., and Kennedy, M. B. (1998). A synaptic RasGTPase activating protein (p135 SynGAP) inhibited by CaM kinase II. Neuron 20, 895-904. doi: 10.1016/S0896-6273(00)80471-7

Chen, L., Yamada, K., Nabeshima, T., and Sokabe, M. (2006). $\alpha 7$ Nicotinic acetylcholine receptor as a target to rescue deficit in hippocampal LTP induction in $\beta$-amyloid infused rats. Neuropharmacology 50, 254-268. doi: 10.1016/j. neuropharm.2005.09.018

Chen, T., Wang, C., Sha, S., Zhou, L., Chen, L., and Chen, L. (2016a). Simvastatin enhances spatial memory and long-term potentiation in hippocampal CA1 via upregulation of $\alpha 7$ nicotinic acetylcholine receptor. Mol. Neurobiol. 53, 4060-4072. doi: 10.1007/s12035-015-9344-6

Chen, T., Zhang, B., Li, G., Chen, L., and Chen, L. (2016b). Simvastatin enhances NMDA receptor GluN2B expression and phosphorylation of GluN2B and GluN2A through increased histone acetylation and Src signaling in hippocampal CA1 neurons. Neuropharmacology 107, 411-421. doi: 10.1016/j. neuropharm.2016.03.028

Cho, C. H., Song, W., Leitzell, K., Teo, E., Meleth, A. D., Quick, M. W., et al. (2005). Rapid upregulation of $\alpha 7$ nicotinic acetylcholine receptors by tyrosine dephosphorylation. J. Neurosci 25, 3712-3723. doi: 10.1523/JNEUROSCI.538903.2005

Colapietro, A. M., Goodell, A. L., and Smart, R. C. (1993). Characterization of benzo[a]pyrene-initiated mouse skin papillomas for Ha-ras mutations and protein kinase C levels. Carcinogenesis 14, 2289-2295. doi: 10.1093/carcin/14. 11.2289

Colon-Saez, J. O., and Yakel, J. L. (2011). The $\alpha 7$ nicotinic acetylcholine receptor function in hippocampal neurons is regulated by the lipid composition of the plasma membrane. J. Physiol. 589, 3163-3174. doi: 10.1113/jphysiol.2011. 209494

Contreras-Vallejos, E., Utreras, E., Borquez, D. A., Prochazkova, M., Terse, A., Jaffe, H., et al. (2014). Searching for novel Cdk5 substrates in brain by comparative phosphoproteomics of wild type and Cdk5-/- mice. PLoS One 9:e90363. doi: 10.1371/journal.pone.0090363

Dann, S. G., Golas, J., Miranda, M., Shi, C., Wu, J., Jin, G., et al. (2014). p120 catenin is a key effector of a Ras-PKCvarepsilon oncogenic signaling axis. Oncogene 33, 1385-1394. doi: 10.1038/onc.2013.91 immunoprecipitation and western blot analysis. BZ carried out the animal care. $\mathrm{LiC}$ and $\mathrm{LZ}$ carried out the experimental design and the preparation of the manuscript.

\section{FUNDING}

This work was supported by grants for National 973 Basic Research Program of China (2014CB943303), National Natural Science Foundation of China (81671253 and 81471157), Jiangsu Provincial Natural Science Foundation of China (BE2016765), and Huaian City Science and Technology Support Program (HAS2015003).

Derkach, V., Barria, A., and Soderling, T. R. (1999). Ca2+/calmodulinkinase II enhances channel conductance of $\alpha$-amino-3-hydroxy-5-methyl-4isoxazolepropionate type glutamate receptors. Proc. Natl. Acad. Sci. U.S.A. 96, 3269-3274. doi: 10.1073/pnas.96.6.3269

Eckert, G. P., Hooff, G. P., Strandjord, D. M., Igbavboa, U., Volmer, D. A., Muller, W. E., et al. (2009). Regulation of the brain isoprenoids farnesyl- and geranylgeranyl pyrophosphate is altered in male Alzheimer patients. Neurobiol. Dis. 35, 251-257. doi: 10.1016/j.nbd.2009.05.005

Endo, A. (2004). The discovery and development of HMG-CoA reductase inhibitors. 1992. Atheroscler. Suppl. 5, 67-80. doi: 10.1016/j.atherosclerosissup. 2004.08.026

Gay, E. A., Giniatullin, R., Skorinkin, A., and Yakel, J. L. (2008). Aromatic residues at position 55 of rat $\alpha 7$ nicotinic acetylcholine receptors are critical for maintaining rapid desensitization. J. Physiol. 586, 1105-1115. doi: 10.1113/ jphysiol.2007.149492

Huganir, R. L., and Greengard, P. (1990). Regulation of neurotransmitter receptor desensitization by protein phosphorylation. Neuron 5, 555-567. doi: 10.1016/ 0896-6273(90)90211-W

Jick, H., Zornberg, G. L., Jick, S. S., Seshadri, S., and Drachman, D. A. (2000). Statins and the risk of dementia. Lancet 356, 1627-1631. doi: 10.1016/S0140-6736(00) 03155-X

Kanno, T., Shimizu, T., Tanaka, A., Nishimoto, T., and Nishizaki, T. (2012a). Free fatty acid derivative HUHS2002 potentiates $\alpha 7 \mathrm{ACh}$ receptor responses through indirect activation of CaMKII. Lipids 47, 865-871. doi: 10.1007/s11745-0123701-2

Kanno, T., Tanaka, A., and Nishizaki, T. (2012b). Linoleic acid derivative DCP-LA stimulates vesicular transport of $\alpha 7 \mathrm{ACh}$ receptors towards surface membrane. Cell Physiol. Biochem. 30, 75-82. doi: 10.1159/000339049

Kanno, T., Yaguchi, T., Nagata, T., and Nishizaki, T. (2012c). Indomethacin activates protein kinase $\mathrm{C}$ and potentiates $\alpha 7 \mathrm{ACh}$ receptor responses. Cell Physiol. Biochem. 29, 189-196. doi: 10.1159/000337600

Kho, Y., Kim, S. C., Jiang, C., Barma, D., Kwon, S. W., Cheng, J., et al. (2004). A tagging-via-substrate technology for detection and proteomics of farnesylated proteins. Proc. Natl. Acad. Sci. U.S.A. 101, 12479-12484. doi: 10.1073/pnas. 0403413101

Kihara, T., Sawada, H., Nakamizo, T., Kanki, R., Yamashita, H., Maelicke, A., et al. (2004). Galantamine modulates nicotinic receptor and blocks A $\beta$-enhanced glutamate toxicity. Biochem. Biophys. Res. Commun. 325, 976-982. doi: 10.1016/ j.bbrc.2004.10.132

Kilkenny, C., Browne, W. J., Cuthill, I. C., Emerson, M., and Altman, D. G. (2012). Improving bioscience research reporting: the ARRIVE guidelines for reporting animal research. Osteoarthr. Cartil. 20, 256-260. doi: 10.1016/j.joca.2012.02.010

Komal, P., Estakhr, J., Kamran, M., Renda, A., and Nashmi, R. (2015). cAMPdependent protein kinase inhibits $\alpha 7$ nicotinic receptor activity in layer 1 cortical interneurons through activation of D1/D5 dopamine receptors. J. Physiol. 593, 3513-3532. doi: 10.1113/JP270469

Laezza, C., Fiorentino, L., Pisanti, S., Gazzerro, P., Caraglia, M., Portella, G., et al. (2008). Lovastatin induces apoptosis of k-ras-transformed thyroid cells via inhibition of ras farnesylation and by modulating redox state. J. Mol. Med. (Berl.) 86, 1341-1351. doi: 10.1007/s00109-008-0396-1 
Lee, S. J., Escobedo-Lozoya, Y., Szatmari, E. M., and Yasuda, R. (2009). Activation of CaMKII in single dendritic spines during long-term potentiation. Nature 458, 299-304. doi: 10.1038/nature07842

Li, L., Qu, W., Zhou, L., Lu, Z., Jie, P., Chen, L., et al. (2013). Activation of transient receptor potential vanilloid 4 increases NMDA-activated current in hippocampal pyramidal neurons. Front. Cell Neurosci. 7:17. doi: 10.3389/fncel. 2013.00017

Liantonio, A., Giannuzzi, V., Cippone, V., Camerino, G. M., Pierno, S., and Camerino, D. C. (2007). Fluvastatin and atorvastatin affect calcium homeostasis of rat skeletal muscle fibers in vivo and in vitro by impairing the sarcoplasmic reticulum/mitochondria Ca2+-release system. J. Pharmacol. Exp. Ther. 321, 626-634. doi: 10.1124/jpet.106.118331

Malinow, R., and Malenka, R. C. (2002). AMPA receptor trafficking and synaptic plasticity. Annu. Rev. Neurosci. 25, 103-126. doi: 10.1146/annurev.neuro.25. 112701.142758

Manabe, T., Aiba, A., Yamada, A., Ichise, T., Sakagami, H., Kondo, H., et al. (2000). Regulation of long-term potentiation by H-Ras through NMDA receptor phosphorylation. J. Neurosci 20, 2504-2511.

Mans, R. A., Chowdhury, N., Cao, D., McMahon, L. L., and Li, L. (2010). Simvastatin enhances hippocampal long-term potentiation in C57BL/6 mice. Neuroscience 166, 435-444. doi: 10.1016/j.neuroscience.2009.12.062

Mans, R. A., McMahon, L. L., and Li, L. (2012). Simvastatin-mediated enhancement of long-term potentiation is driven by farnesyl-pyrophosphate depletion and inhibition of farnesylation. Neuroscience 202, 1-9. doi: 10.1016/j.neuroscience. 2011.12.007

McTaggart, S. J. (2006). Isoprenylated proteins. Cell. Mol. Life Sci. 63, 255-267. doi: 10.1007/s00018-005-5298-6

Mielke, J. G., and Mealing, G. A. (2009). Cellular distribution of the nicotinic acetylcholine receptor $\alpha 7$ subunit in rat hippocampus. Neurosci. Res. 65, 296306. doi: 10.1016/j.neures.2009.08.003

Miyamoto, H., Yaguchi, T., Ohta, K., Nagai, K., Nagata, T., Yamamoto, S., et al. (2003). 2-pyrrolidinone induces a long-lasting facilitation of hippocampal synaptic transmission by enhancing $\alpha 7 \mathrm{ACh}$ receptor responses via a $\mathrm{PKC}$ pathway. Brain Res. Mol. Brain Res. 117, 91-96. doi: 10.1016/S0169-328X(03) 00281-X

Moss, S. J., McDonald, B. J., Rudhard, Y., and Schoepfer, R. (1996). Phosphorylation of the predicted major intracellular domains of the rat and chick neuronal nicotinic acetylcholine receptor $\alpha 7$ subunit by cAMPdependent protein kinase. Neuropharmacology 35, 1023-1028. doi: 10.1016/ S0028-3908(96)00083-4

Nishizaki, T., and Sumikawa, K. (1997). Lysophosphatidic acid potentiates ACh receptor currents by G-protein-mediated activation of protein kinase C. Brain Res. Mol. Brain Res. 50, 121-126. doi: 10.1016/S0169-328X(97)00177-0

Oshikawa, J., Toya, Y., Fujita, T., Egawa, M., Kawabe, J., Umemura, S., et al. (2003). Nicotinic acetylcholine receptor $\alpha 7$ regulates cAMP signal within lipid rafts. Am. J. Physiol. Cell Physiol. 285, C567-C574.

Parent, M. A., Hottman, D. A., Cheng, S., Zhang, W., McMahon, L. L., Yuan, L. L., et al. (2014). Simvastatin treatment enhances NMDAR-mediated synaptic transmission by upregulating the surface distribution of the GluN2B subunit. Cell Mol. Neurobiol. 34, 693-705. doi: 10.1007/s10571-014-0051-z

Pierno, S., Camerino, G. M., Cippone, V., Rolland, J. F., Desaphy, J. F., De Luca, A., et al. (2009). Statins and fenofibrate affect skeletal muscle chloride conductance in rats by differently impairing $\mathrm{ClC}-1$ channel regulation and expression. $\mathrm{Br}$. J. Pharmacol. 156, 1206-1215. doi: 10.1111/j.1476-5381.2008.00079.x

Ren, K., Thinschmidt, J., Liu, J., Ai, L., Papke, R. L., King, M. A., et al. (2007). $\alpha 7$ Nicotinic receptor gene delivery into mouse hippocampal neurons leads to functional receptor expression, improved spatial memory-related performance, and tau hyperphosphorylation. Neuroscience 145, 314-322. doi: 10.1016/j. neuroscience.2006.11.023

Sassano, A., Altman, J. K., Gordon, L. I., and Platanias, L. C. (2012). Statindependent activation of protein kinase $\mathrm{C}$ delta in acute promyelocytic leukemia cells and induction of leukemic cell differentiation. Leuk. Lymphoma 53, 1779-1784. doi: 10.3109/10428194.2012.668287

Sharma, G., and Vijayaraghavan, S. (2003). Modulation of presynaptic store calcium induces release of glutamate and postsynaptic firing. Neuron 38, 929-939. doi: 10.1016/S0896-6273(03)00322-2

Simons, M., Schwarzler, F., Lutjohann, D., von Bergmann, K., Beyreuther, K., Dichgans, J., et al. (2002). Treatment with simvastatin in normocholesterolemic patients with Alzheimer's disease: a 26-week randomized, placebocontrolled, double-blind trial. Ann. Neurol. 52, 346-350. doi: 10.1002/ana. 10292

Thornton, C., Yaka, R., Dinh, S., and Ron, D. (2003). H-Ras modulates $\mathrm{N}$-methyl-D-aspartate receptor function via inhibition of Src tyrosine kinase activity. J. Biol. Chem. 278, 23823-23829. doi: 10.1074/jbc.M30238 9200

Wang, H. Y., Lee, D. H., D’Andrea, M. R., Peterson, P. A., Shank, R. P., and Reitz, A. B. (2000). $\beta$-Amyloid(1-42) binds to $\alpha 7$ nicotinic acetylcholine receptor with high affinity. Implications for Alzheimer's disease pathology. J. Biol. Chem. 275, 5626-5632. doi: 10.1074/jbc.275.8.5626

Wang, J. H., and Kelly, P. T. (1995). Postsynaptic injection of CA2+/CaM induces synaptic potentiation requiring CaMKII and PKC activity. Neuron 15, 443-452. doi: 10.1016/0896-6273(95)90048-9

Wolozin, B., Kellman, W., Ruosseau, P., Celesia, G. G., and Siegel, G. (2000). Decreased prevalence of Alzheimer disease associated with 3-hydroxy-3methyglutaryl coenzyme A reductase inhibitors. Arch. Neurol. 57, 1439-1443. doi: 10.1001/archneur.57.10.1439

Yamamoto, S., Kanno, T., Nagata, T., Yaguchi, T., Tanaka, A., and Nishizaki, T. (2005). The linoleic acid derivative FR236924 facilitates hippocampal synaptic transmission by enhancing activity of presynaptic $\alpha 7$ acetylcholine receptors on the glutamatergic terminals. Neuroscience 130, 207-213. doi: 10.1016/j. neuroscience.2004.09.016

Yan, J. Z., Xu, Z., Ren, S. Q., Hu, B., Yao, W., Wang, S. H., et al. (2011). Protein kinase $\mathrm{C}$ promotes $\mathrm{N}$-methyl-D-aspartate (NMDA) receptor trafficking by indirectly triggering calcium/calmodulin-dependent protein kinase II (CaMKII) autophosphorylation. J. Biol. Chem. 286, 25187-25200. doi: 10.1074/ jbc.M110.192708

Yasuda, R., Harvey, C. D., Zhong, H., Sobczyk, A., van Aelst, L., and Svoboda, K. (2006). Supersensitive Ras activation in dendrites and spines revealed by twophoton fluorescence lifetime imaging. Nat. Neurosci. 9, 283-291. doi: 10.1038/ nn1635

Conflict of Interest Statement: The authors declare that the research was conducted in the absence of any commercial or financial relationships that could be construed as a potential conflict of interest.

Copyright (ङ 2018 Chen, Wang, Zhang, Zhang, Chen, Zhao and Chen. This is an open-access article distributed under the terms of the Creative Commons Attribution License (CC BY). The use, distribution or reproduction in other forums is permitted, provided the original author(s) and the copyright owner are credited and that the original publication in this journal is cited, in accordance with accepted academic practice. No use, distribution or reproduction is permitted which does not comply with these terms. 